\title{
A Study on Effectual Decision Making of Construction Projects in Islamabad, Pakistan: Analyzing the Influence of Risk- Taking Behavior, Leadership Skills, and Business Case Implementation.
}

\author{
RABIA KIANI \\ Management Studies Department, Bahria University Islamabad, Pakistan. \\ Email: rabiakiani@live.com \\ Tel: +923347606909 \\ SALMAN TAHIR \\ Lecturer, Management Studies Department. Bahria University Islamabad, Pakistan. \\ Email: Stahir.buic@bahria.edu.pk \\ Tel: +923435021100 \\ IQRA SARFARAZ \\ Management Studies Department, Bahria University Islamabad, Pakistan. \\ Email: iqra_sarfaraz@outlook.com \\ Tel: +923367885300
}

\begin{abstract}
The purpose of this study is to examine various aspects which include business case implementation, risktaking behavior and leadership skills impacts on construction sector of Islamabad, Pakistan. A questionnaire was prepared for the targeted construction firms. Sample size used for analysis was 215 . On receipt of the data, a comparative analysis is done by using SPSS software to choose the better options. The better option from business case implementation and the leadership skill have been instrumental in the decision making while risk-taking behavior will have no effect on it. Approaches to the Project management are becoming flexible and more adoptive to compete with the challenges arising out of rapidly change environment and complex projects. However, consideration for the possible potential changes regarding decision making in projects is very rare and less discovered. The Effectual decision making approach in the construction industry has rapidly been growing. It seems that gradually the effectuation approach would replace the traditional methods that have long been in the usage.
\end{abstract}

Keywords: Effectual Decision Making, Risk-Taking Behavior, Business Case Implementation, Leadership Skills, Construction Industry.

\section{Introduction}

In the modern world like all other developments taking place rapidly, the construction industry is no exception. It needs to be developed faster to keep pace with the expanding requirements of built-up areas. To achieve the project objectives in given time and other constraints is prime concern in Project management (George, 2020 ). Project management in its wider spectrum would largely depend upon the decision making (Stingl, 2017) based on the available inputs (Kolawole et al., 2020). Since there ensues greater risk in the construction industry for unforeseen reasons (Tayeh et al., 2020); (Ali, 2020), the project 
managers ought to be fully alert and equipped with necessary know-how for damage control (Mac Donald et al., 2020). The project managers may exercise various options to ensure the quality of the work to the entire satisfaction of their clients/customers. No loose ends, supervision is also the most essential aspect as lack of it may cause failure of the construction projects or its sub-standard outcome (Kamal et al., 2019).

The construction industry is the foremost as well as essential sector of any economy which plays a substantial role in an economic development (Ahmed et al., 2020) (Dakhil, 2013), specifically for developing countries (Pham et al., 2019); (Choy et al., 2011). Economy type and current scenarios are also important when it comes to contribution of construction sector (Ahmad et al., 2018); (Wu et al., 2019); (Khan, 2008). Construction industry of Pakistan is currently on second place if we talk about current impact in growth of economy.

The Project decisions are taken by the project managers and the team member of projects (Mahmoudi et al., 2020). Effective and immediate decision making is one of the key skills of project manager (Lutas et al., 2020). In matters relating to the Project management which had been in vogue, the traditional decisionmaking approach is gradually being replaced by the new approaches that can be more effective and useful to the project management in construction sector.

Thinking uniquely and offering ways to influence the unforeseeable future is logic of effectuation logic (Macovei \& Hagen, 2020). The logic of Effectuation is the conducts which are guided by means, emphasis on the risks, form collaboration and control (Pacho \& Mushi, 2020). The effectual approach is still relatively less known for it has recently been operational to implement projects and it is now being adopted by different sectors. (Sarasvathy, 2001) has introduced the logic of effectual decision-making. Which is not an approach focused on predictions. In enterprising writing, two primary points have been described as decision-making procedures for the development of new pursuits: effectual and causal dynamics.

All workers of a team, as the compulsory component of project management, are encouraged to achieve their best capabilities. Managers are responsible (Agyekum et al., 2020) for continuing to track what workers need to accomplish their job objectives in an acceptable manner. The specific role of project managers enables them to dramatically influence and effectively promote market growth at different levels through their management skills and values (Gatsinzi \& Nyambane, 2020); (Hills et al., 2008). Consequently, effectual decision making focuses primarily on realistic losses, taking advantage of contingencies and handling an unforeseeable future (Ijaola et al., 2020); (Perry et al., 2011). The leadership qualities of the project manager, the risk-taking behavior and the manner in which the business case is incorporated or used throughout the project play a major role in successful decision making.

This research is to check the effect of business case execution, leadership skills, and risk-taking actions on successful decision making in the construction industry. The aspect has not yet been studied. The business case consists of five steps: confirmation of opportunity, review \& development of selected options, assessment of options, implementation strategy and recommendations. The business case is helpful to the project and is used in the project (Einhorn, 2019).

The business case contributes its part to the success of the project by mitigating the probability and effect $\mathrm{o}$ $\mathrm{f}$ the failure. Project risk is correlated with all phases of project planning (Naeem et al., 2018), which is why the risk-taking conduct of the project manager has an impact on the decision-making. Risk management in construction project is of utmost importance to get the desired objectives of projects (Haverila et al., 2020).

Leader's knowledge and quality of working give impetus to the organization he is leading (Ali et al., 2020); (Latif et al., 2020). Not only the leader should himself be competent, industrious, untiring, diligent with amiable disposition but hard task master, but be also well aware of the capabilities of his worker and the cooperative methods. If he is so imbued with these qualities his job is made easier and fruitful (Gillin et al., 
2019). On contrary the weak and inept leadership, more or less, would cause colossal losses to the organization resources, in the ultimate analysis proving a total liability. In nutshell, it could be said that without any high-statured qualified leadership attuned to undertaking the arduous tasks with zeal and enthusiasm, any organization for that matter including the construction companies would remain unproductive. Therefore, the greater responsibilities lie with the leadership for accomplishing the given assignments successfully (Mbogoh et al., 2019). The organization's success depends on the strength of its leadership (Rehman, 2020). It should be the endeavor of the project manager to arrive at an effectual decision after weighing all the pros and cons that can produce greater dividends without much ado, to reap benefits without dissatisfying the clients (Thoha \& Avandana, 2020); (Alvarenga et al., 2019). But this all depends upon the skill and proficiency of the leadership that manages all the affairs relating to construction industry under the new system that tends to replace the old practices (Latif et al., 2020); (Gillin et al., 2019).

\section{Significance of the Study}

Once completed, it would ensure completion of the project as smoothly as possible without many pitfalls. It would render great assistance to the project manager in completion of the project with negligible losses and to the entire satisfaction of the organization he is employed with.

\section{Research Objectives}

The fundamental objectives of this study are as follow:

- To study and authenticate the relation between the business case implementation and effectual decision making in construction company in Islamabad.

- To study and authenticate the relation between the risk-taking behavior and effectual decision making in construction company in Islamabad.

- To study and authenticate the relation between the Leadership skills and effectual decision making in construction company in Islamabad.

\section{Research Questions}

As discussed in objectives, that effectual decision making is affected by Business case implementation, risk-taking behavior and leadership. In this research, focus is on how to make effectual decision making to get the successful project as an outcome.

Question 1: Is there any significant relationship between the business case implementation and effectual decision making in Construction Company in Islamabad, Pakistan?

Question 2: Is there any significant relationship between the risk-taking behavior and effectual decision making in Construction Company in Islamabad, Pakistan?

Question 3: Is there any significant relationship between the Leadership skills and effectual decision making in Construction Company in Islamabad, Pakistan?

\section{Literature Review}

Pakistan's growth inter alia now depends upon construction sector that necessitates better planning and execution of construction industry which is often seen as a driver of monetary development, especially in the creation of national wealth (McCartney, 2020) (Khan, 2008). Business can be helpful in attracting neighboring human resource and other resources to effectively utilize as a base if growth and enhanced financial capability (Amanan \& Osei-Amponsah, 2007). The real estate sector has a huge capacity for growth and development in any region (Ahmad et al., 2019). It is necessary to mention numerous issues 
that have an impact on financial growth and change in Pakistan (Khan, 2008). According to (Sarasvathy, 2001) effectuation, a methodology is used to deal with the settlement of choices and the success of market operations in the context of an organization.

\section{Effectual Decision-Making Approach}

Theory of Effectuation (2001) formulated by Saras Sarasvathy. In this approach of decision making, In order to get desired objectives, it is important to determine the next best move, taking into account the available resources, and by utilizing resources and actions to counteract these objectives. Approaches that are now commonly used are performance and causal reasoning. Causal logic was presented by (Sarasvathy, 2001) on the grounds of its inadequacy in the process of entrepreneurship and argues that risk and uncertainties are inherent in the process of entrepreneurship. Logic of effectuation describe the future which can be controlled by actions and imagine a potential result that can generate opportunities for them (Guo et al., 2020).

\section{Business Case Implementation and Decision Making}

Garbage Can Theory have presented by (Cohen et al., 1972) which outlines the components in decisionmaking process. Theory shows that decisions are the result of challenges, solutions, members, and options available in organizations.

Business case observes the advantages, costs \& risks of alternatives solutions and try to make justifications. It also justifies the undertaking of a project, program, and portfolio. We basically use two types of approaches while taking decisions that involve a controlled thinking process and an automatic, unconscious thinking process (Venkatraman \& Wittenbraker, 2020). Human mind can create relations in information which is received and stores in the memory for future use (De Winnaar \& Scholtz, 2019).

Managers are expected to collect requirements of the stakeholders and keep them in consideration while taking decisions (Unterhitzenberger et al., 2020); (Di Maddaloni \& Davis, 2018), whereas overloaded knowledge and limitations on the enterprise make implementation difficult. Project management was pervaded by the belief that the use of a linear assessment tool should be commonly used, depending on the context, to promote the decision-making process in the project. Intuition judgement and the vision are considered to be essential resources for effective strategic project and program management.

As pretty clear from the name, a business case assesses the advantages and disadvantages of the project that is in its preliminary planning phase, warranting a person to initiate it. It involves Cost Benefit Analysis carried out either via Expert Judgment or any other prevalent tool/technique in that particular domain. The foremost things to be taken care of, at this stage, are the statistics that support the business case, in the first place. This actually helps the initiator to reduce the risks of possible choices and supports the favored arrangement. The Business Case oriented projects have been proved to show effective results, helping people either start a project or choose one among different options. Literature indicates that use of business case contributes to the achievement of the project (Musawir et al., 2017).

The key point that this research highlights is a gap that was left unnoticed in the previous research regarding the usage of business cases. One of the main reasons found out in this regard is that the Business Case model, despite being appreciated and accepted worldwide, is underutilized. It is a common observation that a business case is referred to, mostly in the starting phase of the project, revolving mostly around the planning phase. On the other hand, the researches show that the relevance of the business case is almost equal to the life of the project (Marnewick \& Marnewick, 2020). 


\section{Risk-Taking Behavior and Decision Making}

For any leadership, Prospect theory is a tricky theory in the sense that while adjusting all pros and cons, weightage needs to be given to perceived benefits and pulling aside the loss-causing factors. No client will favor any loss to him. So the project manager has to put greater emphasis on cost-effectiveness of the construction projects. The theory was firstly introduced in 1979 and in 1992 Amos and Daniel presented it with amendments (Tversky, 2013). The isolation effect only occurs when two separate choices are offered but their conclusion almost identical. This would be the inhibiting factor to accept the offer. It is therefore of paramount importance to frame the options very candidly to make them appear.

The prospect theory simply refers to the losses or profits attributed to the investor. However, what matters more are the perceived gains instead of losses. This can be understood in a simple way that if an investor is facing a dilemma of going with one out of two choices, there is a strong probability that he/she would go with the option that stands more chances of profit instead of losses. This is exactly what the prospect theory says, backed by the researches made as a part of behavioral economics domain. Simply put, the prospect theory warrants a package with perceived gains as any mention loss would be emotionally unsound. The client with likelihood offers of additions would be more disposed to acknowledge than dismissing in any case as could be required by confinement impact.

One who is following the prospect theory will probably settle on the choices that might show hazards and vulnerabilities e.g. percentage probability of losses or gains. It has been observed that the one on the path of following the prospect theory will have an optimist mindset, focusing on the positive aspect of the anticipated results instead of minding the possible negative repercussions. This warrants the prospect theory developers to exclude the negative hazards to make it more appealing to the people who would rather hate to even go through the anticipated misfortunes. To satisfy their selves, the people in discussion would probably distance themselves from any related negative thoughts, giving them a feeling of hope. However, a fallout plan in such case is what they would like to have.

Derived from the definition, is the concept of Risk-taking behavior which is a trait found in a huge number of project initiators. This behavior forces them to follow a way of handling a situation or condition without worrying about adverse consequences (Cowie, 1989). There are many inborn flaws and problems facing the construction industry. Hazard tendency is conceptualized as an individual trait that can be modified after some time, rather than as a steady and consistent layout mark (Yordanova, 2011). The consequence of individual risk-taking actions, either knowingly or through lack of care, is one the key contributory variables to the event. Employee injuries are said to continue to be a major financial problem for the employees due to immediate costs. According to (Low et al., 2019), the risk-taking behavior was influenced by many factors which could be personal, team members and organizational.

\section{Leadership Skills and Decision Making}

The test of pudding lies in its eating ${ }^{l}$. So the leaders face a challenge of making fulsome decisions. More importantly they must get the proper input and seeking consultation with the team. The time spent on preconsultations for eliciting group contribution, would add to reaching at a viable and useful decision as per the theory of (Vroom \& Yetton, 1973) leader can avail as much options as he can either by deciding himself or by obtaining useful information from wherever he can lay his hand on. He must be well- versed his job and loyal to the organization he has been placed with. A carefully made decision will not only add to his nature and would be beneficial in the long run and a credit at its implementation stage. No snags be lift while making decisions.

\footnotetext{
${ }^{1}$ William Camden (1605)
} 
The leadership is not simply a word. It encompasses wide ranging qualities that determine a true leader. A leader must be professionally competent, hardworking, and diligent with a cheerful disposition towards his subordinates. And at the same hard taskmaster, he must preserve in arduous undertakings. The leader must possess a special aptitude for construction work and be promptitude of actions in emergencies. And above all should have abundance capacity for organizing the labour to add to the profitability of any undertaking. Decision making, particularly in the construction outfits is cumbersome for the leadership. From various simple and complex matters, the leadership has to strive strenuously to pick up the inputs that could help in arriving at correct decision beneficial for the construction industry in general and leader's organization in particular. The construction industry and its growth will always be dependent upon the quality of its leadership and the working aptitude of the labour under the supervision of a leader. Any failures on the part of leadership would be damaging from both organizational and national points of view (Almansour, 2012). Leader's relation with the workers must be amiable and redressal of their problems is also part of his vision. The objective, on the whole, must be the cooperative attitude for the fulfilment of the construction jobs to the satisfaction of the clients and for beneficial gains to the construction company itself.

\section{Theoretical Framework}

Based on literature we have discussed above, our framework shown in Figure.1, depicting a relationship of three independent variables.

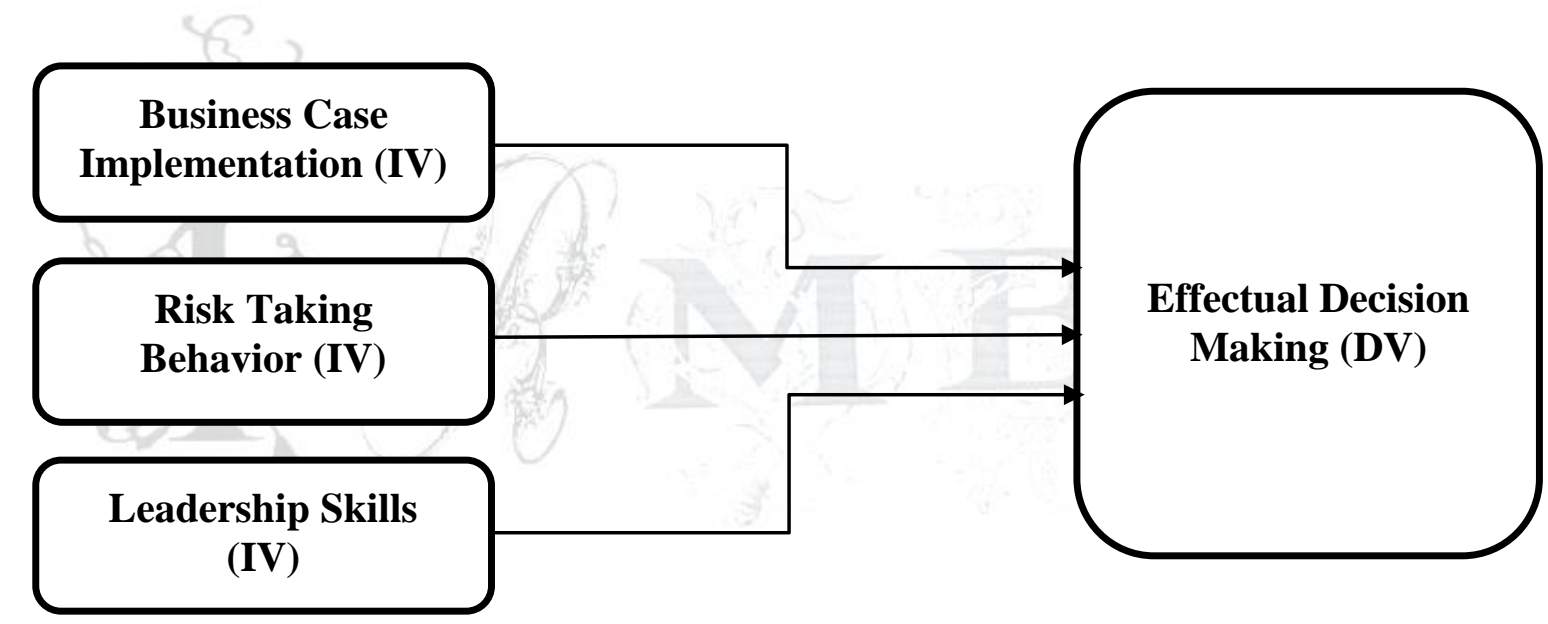

Figure 1: Conceptual framework of the study

\section{Effectual Decision Making (Dependent variable)}

While following the developing methods and non-prescient technique, Effectuation procedure become more consistent (Sarasvathy, 2001);( Chandler et al., 2011). Talking about decision making, it is one of the major tools of project manager and core competency in project management.

Effectual decision making includes but is not limited to:

- It always starts with Means driven.

- Always look for the ways to get benefits.

Decision making with effectuation initiates with specific means and looking to get new ends with help of unpredictive strategies. Effectual decision making got adopted in different industries with a positive impact. Construction Industry which we are taking for our research has great potential and in dire need to adopt this technique to have better and efficient outcomes. 


\section{Business case Implementation (Independent variable)}

In general, elements included in business case are specific and starts before any of the process group of project management. In view of literature available and project management experts it is quite a difficult task to cover every bit of o single process group throughout the duration of project. Business case impact on effectual decision making has a negative impact when studied alone (Nguyen et al., 2018). But in our research, we are testing it in combination.

\section{Risk Taking Behavior (Independent variable)}

Risk taking behavior is relative from person to person and industry to industry. To keep it as independent variable in this paper is to get the idea of uncertainty and impact on effectual decision making. Particularity in construction industry, a lot of risks related to human, financial and schedule to handle and decision making on particular situation affect a lot.

\section{Leadership Skills (Independent variable)}

Trait of leadership along with decision making power of project manager has great impact if used in collaboration. Construction industry is full of issues like conflict between teams, cultural diversity and other. If leadership skill is not there, it may cause serious project delayed timelines.

\section{Hypothesis}

Based on conceptual model, following are the hypothesis:

H1: Business case implementation significantly impact effectual decision making in construction Projects.

H2: Risk-taking behavior significantly impact effectual decision making in Construction Projects.

H3: Leadership skills significantly impact effectual decision making in Construction Projects.

\section{Methodology}

In this research positivism philosophy and deductive approach was adopted. Online google forms were used to conduct this survey from various construction companies located in Islamabad, Pakistan. The sample size for given population of 480 is approximately 214 respondents $^{2}$. The sample size for carrying out the analysis was 215. The questionnaire used in this study was adapted. Five point Likert scale was used to get responses on all variables and for findings and interpretation of results SPSS software was used in order to conduct different tests.

\section{Analysis}

Gathering of quantitative data, statistical analysis results and findings' interpretation have been reviewed in this analysis section.

\section{Descriptive Analysis}

Descriptive statistics and frequencies (sample profile) are included in descriptive analysis.

\footnotetext{
2 According to Uma Sekaran (2003)
} 
Frequencies (Sample profile)

Demographic test using SPSS was carried out to give frequencies.

\section{Age Frequency of Respondent}

Mostly respondents were belonged to the age group 26-35 as shown in the table 1. 19 respondents out of 215 were from 18-25 age group, 151 were from 26-35 age group, 39 were from 36-45 age group whereas 6 respondents were more than 45 years old.

Table 1: Frequencies related to Age of Respondents

\begin{tabular}{|ccccc|}
\hline Age & Frequency & \% & Valid \% & Cumulative \% \\
\hline $18-25$ & 19 & 8.84 & 8.84 & 8.8 \\
$26-35$ & 151 & 70.23 & 70.23 & 79.07 \\
$36-45$ & 39 & 18.14 & 18.14 & 97.21 \\
Above 45 & 6 & 2.79 & 2.79 & 100 \\
Total & $\mathbf{2 1 5}$ & $\mathbf{1 0 0 . 0}$ & $\mathbf{1 0 0 . 0}$ & \\
\hline
\end{tabular}

\section{Descriptive Statistics}

The information related to descriptive statistics is shown in table 2. Results of this test shows that Respondents had positive opinion about the values of variables we have in this study. Effectual decision making (EDM) mean is 3.951, Business case implementation (BCI) mean is 3.831, Risk-taking behavior (RTB) means is 3.423 \& Leadership skills (LS) mean values is 4.014 while the standard deviation values are $0.650,0.752,0.607$, and 0.495 respectively. Range of variables is from 3.423 and 4.014 which on Likert scale is the option 3 corresponds to Neutral and 4 to Agree, we considered that the option selected by respondents is ranging from 3 to 4 .

The normality variables are assessed through the Skewness and Kurtosis. (Brown, 2006) ; (Kline, 2011), the values of acceptance of Skewness ranges from -3 and +3 , and the range of Kurtosis acceptance is -10 to +10 . Result shows that variables are in acceptable range which shows the variable normality.

Table 2: Descriptive statistics

\begin{tabular}{|clllllllll|}
\hline & \multicolumn{1}{c}{ Min } & \multicolumn{2}{c}{ Max } & \multicolumn{2}{c|}{ Mean } & \multicolumn{2}{c|}{ Std. Dev } & \multicolumn{3}{c|}{ Skewness } & \multicolumn{3}{c|}{ Kurtosis } \\
\hline EDM & 215 & 1.25 & 5.00 & 3.9512 & .65071 & -1.114 & .166 & 1.938 & .330 \\
BCI & 215 & 1.00 & 5.00 & 3.8310 & .75289 & -1.512 & .166 & 2.796 & .330 \\
RTB & 215 & 1.11 & 5.00 & 3.4233 & .60797 & -1.415 & .166 & 3.325 & .330 \\
LS & 215 & 1.10 & 5.00 & 4.0140 & .49577 & -.992 & .166 & 4.642 & .330 \\
\hline
\end{tabular}

\section{Reliability Analysis}

Cronbach's Alpha is used to assess the reliability statistics which are shown in table 3. Internal Consistency and reliability were measured using this test. (Hulin, 2001). 0.6 to 0.7 are considered as the good reliability's acceptance level whereas 0.8 or above is considered as very good reliability level.Cronbach's Alpha for Effectual decision making is 0.707, for Business case implementation is 0.704, for Risk taking behavior is 0.702 and for Leadership skill is 0.754 . They are showing good reliability and are in the acceptance range. 
Table 3: Reliability Statistics

\begin{tabular}{|ccc|}
\hline Variables & No. of Items & Cronbach's Alpha \\
\hline EDM & 4 & 0.707 \\
BCI & 3 & 0.704 \\
RTB & 9 & 0.702 \\
LS & 10 & 0.754 \\
\hline
\end{tabular}

\section{Construct Validity}

There are two types of construct validity, Convergent validity, and Discriminant validity. In this study Discriminant validity will be used.

\section{Correlation Analysis}

Correlation is the relation between inter item and variables. SPSS software with the significance level of ( $p$ $<0.01$ and $\mathrm{p}<0.05$ ) is used to test the Correlation shown in table 4.5. As all the values are within the level of significance that means there is significant correlation among variables.

All pair of models possess positive Correlation among them as shown by the test results. There is moderately strong positive Correlation of 0.439 between Effectual decision making (EDM) and Business Case Implementation (BCI) which indicates that both variables move in same direction e.g. if the impact of one variable increases than the other variable's impact will also increase.

The correlation value among the pair of models must not exceed 0.9 as it represents the presence of multicollinearity in model. As all the values of pairs shown in this table are less than 0.9 so, there is no problem of multicollinearity.

Table 4: Correlation

\begin{tabular}{|ccccc|}
\hline & EDM & BCI & RTB & LS \\
\hline EDM & 1 & & & \\
BCI & $.439^{* *}$ & 1 & 1 & \\
RTB & .126 & $.214^{* *}$ & .016 & 1 \\
LS & $.299^{* *}$ & $.306^{* *}$ & .016 \\
\hline
\end{tabular}

**. Correlation is significant at the 0.01 level (2-tailed).

\section{Exploratory Factor Analysis (EFA)}

Exploratory Factor Analysis (EFA) results are shown in table 5. The KMO value is 0.629 which is greater than 0.5 which shows the strength of data. If $p$ value is greater than the given value, then the Bartlett's test of sphericity is considered significant. In this table value is 0.000 which is less than $p$ value $(0.001)$ which shows that the factor analysis is appropriate and a reliable and valid instrument used in this study.

Table 5: KMO and Bartlett's Test

\begin{tabular}{|ccc|}
\hline \multicolumn{2}{|c|}{ Kaiser-Meyer-Olkin Measure of Sampling Adequacy } & .629 \\
\hline \multirow{3}{*}{ Bartlett's Test of Sphericity } & Approx. Chi-Square & 85.062 \\
& Df & 6 \\
& Sig. & .000 \\
\hline
\end{tabular}




\section{Total Variance Explained}

Table 6, For factor analysis, all the subjected items whose sum should be equal to the extracted factors are shown by Eigenvalue. There are three sub-sections of Eigenvalue table. Extracted Sums of Squared Loadings are used for interpretation and analysis purpose. The account for first factor is $44.031 \%$ of the variance, whereas the remaining three factors are not significant.

Table 6: Total Variance Explained

\begin{tabular}{|ccccccc|}
\hline Component & \multicolumn{3}{c}{ Initial Eigenvalues } & \multicolumn{3}{c|}{ Extraction Sums of Squared Loadings } \\
& Total & Variance & $\begin{array}{c}\text { Cumulative } \\
\%\end{array}$ & Total & Variance & $\begin{array}{c}\text { Cumulative } \\
\%\end{array}$ \\
\hline 1 & 1.761 & 44.031 & 44.031 & 1.761 & 44.031 & 44.031 \\
2 & .992 & 24.810 & 68.841 & & & \\
3 & .697 & 17.423 & 86.264 & & & \\
4 & .549 & 13.736 & 100.000 & & & \\
\hline
\end{tabular}

Extraction Method: Principal Component Analysis.

\section{Scree Plot}

Figure 2 shows the scree plot. The Eigenvalues against all the extracted factors are shown by the scree plot graph. To determine the amount of retaining factors, this graph is helpful. In the following graph, the factor 2 starts to flatten onwards curve and has less than 1 Eigenvalue, so only 1 factor has been retained and this is the only point of interest in this graph.
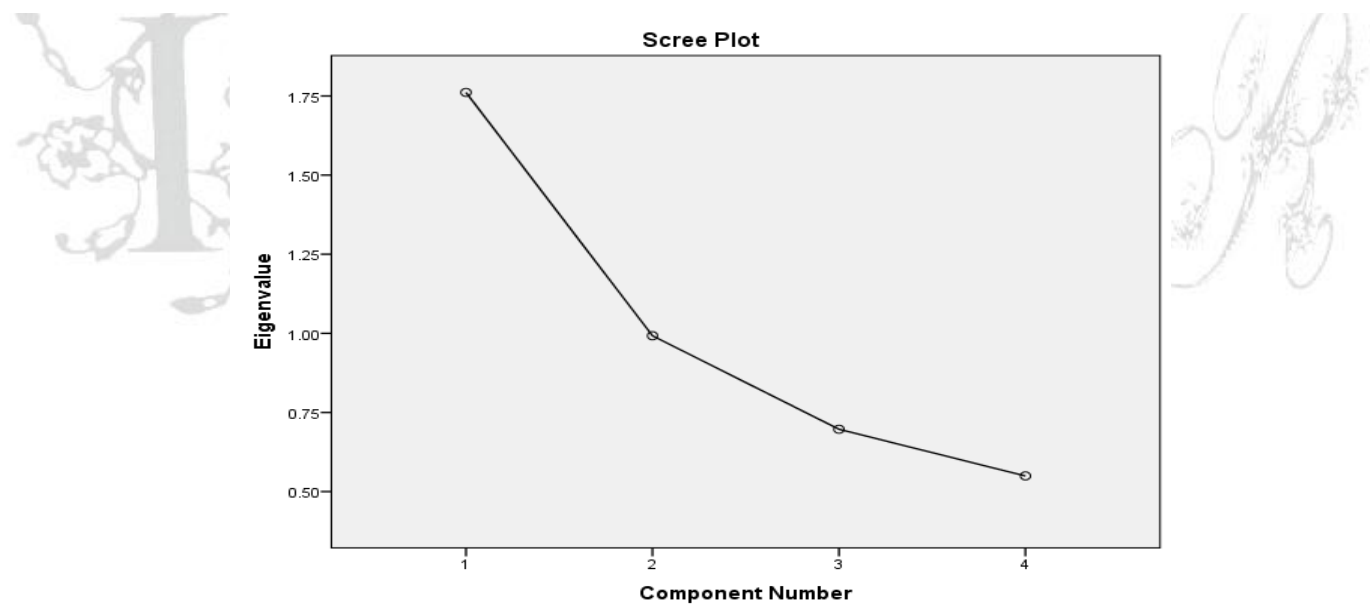

Figure 2: Scree plot

\section{Hypothesis Testing}

Multiple Regression Analysis is tested in this study. The relationship of single dependent or outcome with two or more independent variables can be examined using Multiple regression analysis. The model summary of multiple regression analysis is shown in table 7. How nicely the model and data fits together is determined by Model summary.

In this model summary, the percentage of variation is depicted by $\mathrm{R}$ Square in the response of the model. The higher the value of R Square the better it is considered for the model data. The R Square range lies between 0 to 100 percent. 
If there is any need to see the comparison when different predictors are used by model Adjusted R Square is used. The correct model can be chosen by combining the number of predictors with the help of adjusted $\mathrm{R}$ square value.

The R Square value of the Business Case Implementation in this table is 0.192, which means that there is 19.2\% impact of Business Case Implementation on the Effectual Decision Making. R Square value of the Business Case Implementation (BCI) and Risk-taking Behavior (RTB) is 0.193 which means if we add one variable then the impact on the dependent variable (EDM) will also be increased. The value of $\mathrm{R}$ square of BCI, RTB and LS is $0.224(22.4 \%)$ which shows that the addition of one more variable will increase the impact on the dependent variable.

Table 7: Model Summary

\begin{tabular}{|ccccc|}
\hline Model & R & R Square & $\begin{array}{c}\text { Adjusted R } \\
\text { Square }\end{array}$ & $\begin{array}{c}\text { Std. Error of the } \\
\text { Estimate }\end{array}$ \\
\hline 1 & $.439^{\mathrm{a}}$ & .192 & .189 & .58617 \\
2 & $.440^{\mathrm{b}}$ & .193 & .186 & .58715 \\
3 & $.473^{\mathrm{c}}$ & .224 & .213 & .57729 \\
\hline
\end{tabular}

a. Predictors: (Constant), BCI

b. Predictors: (Constant), BCI, RTB

c. Predictors: (Constant), BCI, RTB, LS

The ANOVA table (8) tests the fitness of overall regression model. The value of $F_{1}(1,213)=50.713, p<$ $.000^{3}$ shown by this table means that the BCI (independent variable) statistically significantly predicts the EDM (dependent variable). $\mathrm{F}_{2}(2,212)=25.417, \mathrm{p}<.000$ which means that the BCI and RTB (independent variables) statistically significantly predicts the EDM (dependent variable). $\mathrm{F}_{3}(3,211)=20.298$, $\mathrm{p}<.000$ which means that the BCI, RTB and LS (independent variables) statistically significantly predicts the EDM (dependent variable).

Table 8: ANOVA $^{\mathrm{a}}$

\begin{tabular}{|c|c|c|c|c|c|c|}
\hline & Model & $\begin{array}{l}\text { Sum of } \\
\text { Squares }\end{array}$ & Df & $\begin{array}{c}\text { Mean } \\
\text { Square }\end{array}$ & $\mathbf{F}$ & Sig. \\
\hline \multirow[t]{3}{*}{1} & Regression & 17.425 & 1 & 17.425 & 50.713 & $.000^{b}$ \\
\hline & Residual & 73.187 & 213 & .344 & & \\
\hline & Total & 90.612 & 214 & & & \\
\hline \multirow[t]{3}{*}{2} & Regression & 17.525 & 2 & 8.763 & 25.417 & $.000^{\mathrm{c}}$ \\
\hline & Residual & 73.087 & 212 & .345 & & \\
\hline & Total & 90.612 & 214 & & & \\
\hline \multirow[t]{3}{*}{3} & Regression & 20.294 & 3 & 6.765 & 20.298 & $.000^{\mathrm{d}}$ \\
\hline & Residual & 70.318 & 211 & .333 & & \\
\hline & Total & 90.612 & 214 & & & \\
\hline
\end{tabular}

a. Dependent Variable: EDM

b. Predictors: (Constant), BCI

c. Predictors: (Constant), BCI, RTB

d. Predictors: (Constant), BCI, RTB, LS

\section{Coefficients}

Table 9: Estimate Model Coefficients

The following equations were get from this table;

\footnotetext{
3 (significantly greater than zero)
} 
$\mathrm{EDM}_{1}=2.499+(0.379 * \mathrm{BCI})$

$\mathrm{EDM}_{2}=2.399+(0.373 * \mathrm{BCI})+(0.036 * \mathrm{RTB})$

$\mathrm{EDM}_{3}=1.588+(0.322 * \mathrm{BCI})+(0.046 * \mathrm{RTB})+(0.241 * \mathrm{LS})$

The amount of variation in dependent variable caused by independent variable when all other variables remain constant is depicted by an unstandardized coefficient. The value of BCI is 0.379 in the $1^{\text {st }}$ equation which shows that there is an impact of 0.379 in Effectual Decision Making with every change in Business Case Implementation. All other variables remain constant in $2^{\text {nd }}$ equation whereas the value of Business Case Implementation and Risk-taking Behavior is 0.373 and their impact on Effectual Decision Making is 0.36. Business Case Implementation, Risk-taking Behavior and Leadership skills have an impact of 0.322 , 0.046 and 0.241 respectively on Effectual Decision Making if all the other variables kept constant.

$\mathrm{T}$ and significance value are used to analyze the statistical significance test. The values of $\mathrm{p}$ of variables BCI and LS are less than 0.05 in this table, which depicts the statistically significance of coefficients whereas the value of RTB is greater than the significance level 0.05 which means that coefficients are not statistically significant.

Table 9: Coefficients ${ }^{\mathrm{a}}$

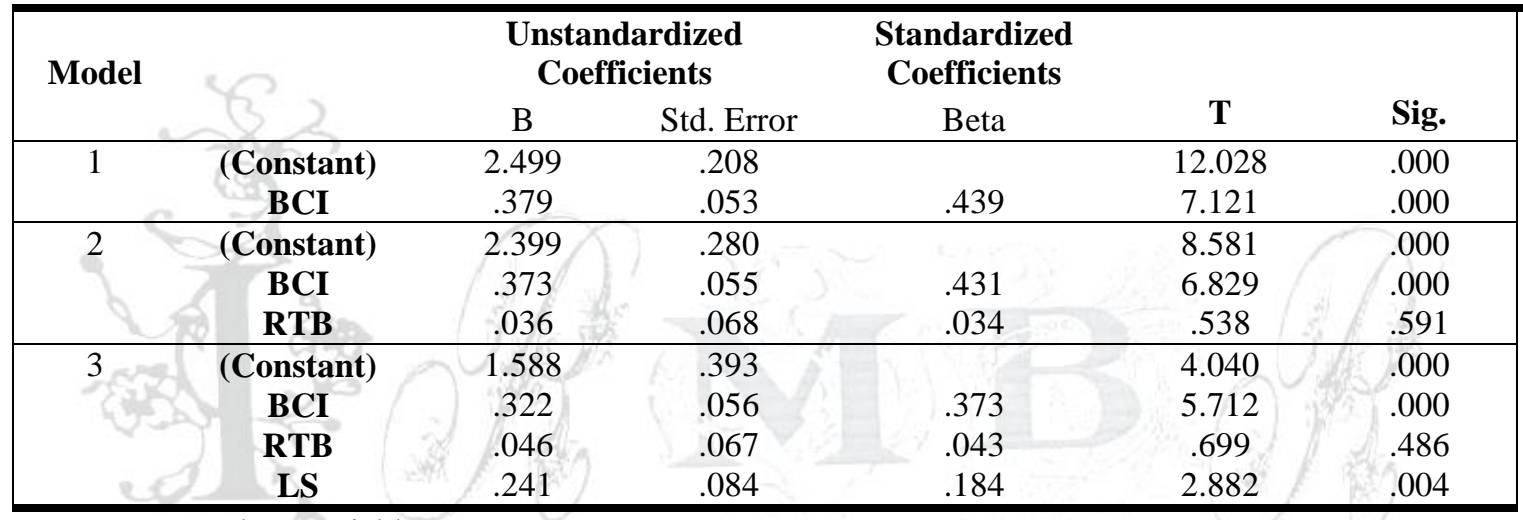

a. Dependent Variable: EDM

\section{Results}

First hypothesis which is business case implementation significantly impact effectual decision making in construction Projects is accepted, because the value of beta is 0.373 .

Second hypothesis which is risk-taking behavior significantly impact effectual decision making in Construction Projects is rejected, because the value of beta is 0.043 .

Third hypothesis which is leadership skills significantly impact effectual decision making in Construction Projects is accepted, because the value of beta is 0.184 .

\section{Discussion and Conclusion}

As compare to the previous research conducted on effectual decision making, this research finds a significant relationship of risk-taking behavior, business case implementation and leadership skills on effectual decision making. Construction industry in Islamabad has a direct impact of leadership qualities on effectual decision making (Nguyen et al., 2018). Results of our research conclude a unique context of different indicators like business case implementation, risk-taking behavior and leadership skills on effectual decision making in construction industry of Pakistan. It shows that the direct and positive impact 
of business case implementation and leadership skills on effectual decision making but the same study is contradicting the risk-taking behavior indicator and its impact on effectual decision making comparing to another previous research. It also shows that people are more focusing on effectual decision making as it is one of the more flexible and adaptive approach, and it can be widely use and give positive results too in other sectors or industries.

First hypothesis was business case implementation significantly impact effectual decision making in construction Projects, results of study shows that the business case implementation is another factor with more direct impact as compare to leadership skills in effectual decision making. Managers, who are involved in early stages of project management, are more focus towards business case implementation.

Risk-taking behavior is an approach of managers in project management and the construction industry is full of risks (Azari et al., 2011) while considering this, second hypothesis was developed for this research. Which is risk-taking behavior significantly impact effectual decision making in Construction Projects. Results related to this hypothesis shows that risk taking behavior of manager is not directly impacting the effectual decision-making process. Managers are more concerned to avoid risks or to come up with the decision where less risk is involved even if they are seeing a huge opportunity of success, still they want to take minimum of the risk.

Project success is directly proportional to right decisions taken at right time of project management processes, particularly in construction projects where project successes can be measured in easy terms. Effectual decision making is not a conventional technique and was first introduced by Sarasvathy in 2001. Results of Study reveal about the third hypothesis, which is leadership skills significantly impact effectual decision making in Construction Projects that from top to middle level management personal are enthusiastic and want to exercise their leadership skills while taking decision. They just do not want to force their decision on employs which is a very positive sign in today's management system. Results also showed that this trend is more prominent in middle level management.

This research has a widespread implication for Business implementation strategies, risk taking behavior and leadership skills on Effectual decision making especially for construction industries but also the subsidiaries industries related to construction and real estate. Firstly, the construction industry should make best possible use of business case implementation in decision making to get maximum benefit and make projects successful. Secondly, Leadership skills must be utilized and exercised while making any decision related to project management processes or the life cycle to get confidence of team players along with employees' satisfaction. It is observed that managers in construction industries are lacking risk taking behavior in project success which sometimes leads to wrong decisions. Risks are part of projects and must be entertained in a manner that positive risks should be utilized and minimize the negative risk for project success.

\section{Limitation and Future Directions}

On the same side, this study has many limitations when it comes to sample size, data collection, time constraints and one of the major limitations we have experienced is the COVID-19 pandemic situation because of which we had to limit the size of study demographically and physical presence for data collection. For this study, we had to depend a lot on virtual data collection. Effectual decision making is a new approach when it comes to the construction industry of Pakistan so to introduction of this concept was a tough ask virtually. For future research, the sample size should be increased, and the study must be conducted in other demographics to assess and have a wider scope and more research generalization. Researchers in future may also look for the subsidiary industries of construction to examine the impact of indicators on effectual decision making. Finally, one of the future perspectives for this research is to compare the results of indicators across industries, different cities and with international borders to look for gaps and implications. 


\section{References}

Agyekum, K., Kissi, E., Danku, J. C., Ampratwum, G., \& Amegatsey, G. S. (2020). Factors driving the career progression of construction project managers. Journal of Engineering, Design and Technology, 18(6), 1773-1791. doi:10.1108/jedt-09-2019-0242

Ahmad, M., Zhao, Z.-Y., \& Li, H. (2019). Revealing stylized empirical interactions among construction sector, urbanization, energy consumption, economic growth and $\mathrm{CO} 2$ emissions in China. Science of The Total Environment, 657, 1085-1098. https://doi.org/10.1016/j.scitotenv.2018.12.112

Ahmad, S. B. S., Mazhar, M. U., Bruland, A., Andersen, B. S., Langlo, J. A., \& Torp, O. (2020). Labour productivity statistics: a reality check for the Norwegian construction industry. International Journal of Construction Management, 20(1), 39-52. https://doi.org/10.1080/15623599.2018.1462443

Ahmed, S., Islam, H., Hoque, I., \& Hossain, M. (2018). Reality check against skilled worker parameters and parameters failure effect on the construction industry for Bangladesh. International Journal of Construction Management, 20(5), 480-489. https://doi.org/10.1080/15623599.2018.1487158

Ali, M., Li, Z., Khan, S., Shah, S.J. and Ullah, R. (2020), "Linking humble leadership and project success: the moderating role of top management support with mediation of team-building", International Journal of Managing Projects in Business, Vol. ahead-of-print No. ahead-of-print. https://doi.org/10.1108/IJMPB-01-2020-0032

Ali, S. J. (2020). Most common accidents and best safety strategies to reduce accidents in Northern Iraq construction projects. International Journal of Advanced Engineering, Sciences and Applications, 1(3), 30-36. https://doi.org/10.47346/ijaesa.v1i3.47

Almansour, Y. M. (2012). The relationship between leadership styles and motivation of managers conceptual framework. Journal of Arts, Science, and Commerce, 3(1), 161-166.

Alvarenga, J. C., Branco, R. R., Guedes, A. L. A., Soares, C. A. P., \& Silva, W. S. (2019). The project manager core competencies to project success. International Journal of Managing Projects in Business, 13(2), 277-292. https://doi.org/10.1108/ijmpb-12-2018-0274

Anaman, K. A., \& Osei-Amponsah, C. (2007). Analysis of the causality links between the growth of the construction industry and the growth of the macro-economy in Ghana. Construction Management and Economics, 25(9), 951-961. https://doi.org/10.1080/01446190701411208

Azari, A. R. K., Mousavi, N., Mousavib, S. F., \& Hosseinia, S. B. (2011). Risk assessment model selection in construction industry. Expert Systems with Applications, 38(8), 9105-9111. https://doi.org/10.1016/j.eswa.2010.12.110

Chandler, G. N., DeTienne, D. R., McKelvie, A., \& Mumford, T. V. (2011). Causation and effectuation processes: A validation study. Journal of Business Venturing, 26(3), 375-390. https://doi.org/10.1016/j.jbusvent.2009.10.006

Choy C.F., Skitmore M., Runeson G., \& Bridge A. (2011). Property investment, construction and economic growth: the case of Malaysia. In The Asian Conference on Real Estate (ACRE 2011) Sustainable Growth, Management Challenges, 3-5 October 2011, Thistle Johor Bahru, Malaysia.

Cohen, M. D., March, J. G. \& Olsen, J. P. (1972). A garbage can model of organizational choice, Administrative Science Quarterly, 17, 1-25.

Cowie, A. (1989). Oxford advanced learner's dictionary of current english. Oxford University Press. U.K.

Dakhil, A. (2013, October). The contribution of the construction industry to economic development in libya. Liverpool John Moores University.

De Winnaar, K., \& Scholtz, F. (2019). Entrepreneurial decision-making: new conceptual perspectives. Management Decision, 58(7), 1283-1300. https://doi.org/10.1108/md-11-2017-1152

Di Maddaloni, F., \& Davis, K. (2018). Project manager's perception of the local communities' stakeholder in megaprojects. An empirical investigation in the UK. International Journal of Project Management, 36(3), 542-565. https://doi.org/10.1016/j.ijproman.2017.11.003

Einhorn, F., Marnewick, C., \& Meredith, J. (2019). Achieving strategic benefits from business IT projects: The critical importance of using the business case across the entire project lifetime. International Journal of Project Management, 37(8), 989-1002. https://doi.org/10.1016/j.ijproman.2019.09.001 
Gatsinzi, E., \& Nyambane, D. (2020). Impact of Managers' Soft Skills on Project Performance in Rwanda. International Journal of Economics and Business Administration, 6(2), 72-77.

Gillin, L. M., Gagliardi, R., Hougaz, L., Knowles, D., \& Langhammer, M. (2019). Teaching companies how to be entrepreneurial: cultural change at all levels. Journal of Business Strategy, 40(2), 59-67. https://doi.org/10.1108/jbs-09-2017-0138

Guo, R., Lv, X., Wang, Y., Chaudhry, P. E., \& Chaudhry, S. S. (2020). Decision-making logics and hightech entrepreneurial opportunity identification: The mediating role of strategic knowledge integration. Systems Research and Behavioral Science, 37(4), 719-733. https://doi.org/10.1002/sres.2713

Haverila, M., Haverila, K.C. and Twyford, J.C. (2020), "Critical variables and constructs in the context of project management: importance-performance analysis", International Journal of Managing Projects in Business, Vol. ahead-of-print No. ahead-of-print. https://doi.org/10.1108/IJMPB-02-2020-0071

Hills, M., Fox, P., Hon, C., Fong, P., \& Skitmore, M. (2008). The role of project managers in construction industry development. In Bridge, Carolyn, Eds. Proceedings AACE International's 52nd Annual Meeting \& ICEC's 6th World Congress on Cost Engineering, Project Management and Quantity Surveying, 14.1-14.9.

Ijaola, I. A., Omolayo, O. H., \& Zakariyyh, K. I. (2020). Project Manager's Skills Acquisition: A Comparative Study of Indigenous and Multinational Construction Firms. Journal of Engineering, Project, and Production Management, 10(1), 71-79. https://doi.org/10.2478/jeppm-2020-0009

Kahneman, D., \& Tversky, A. (1979), Prospect Theory: An Analysis of Decision under Risk, Econometrica, 47(2), 263-292.

Kahneman, D., and Tversky, A. (2013). "Prospect theory: an analysis of decision under risk," in Handbook of the Fundamentals of Financial Decision Making World Scientific Handbook in Financial Economics Series, eds L. C. MacLean and W. T. Ziemba (Toh Tuck Link: World Scientific), 99-127.

Kamal, A., Abas, M., Khan, D., \& Azfar, R. W. (2019). Risk factors influencing the building projects in Pakistan: from perspective of contractors, clients and consultants. International Journal of Construction Management, 1-17. https://doi.org/10.1080/15623599.2019.1683693

Khan, R. A. (2008). Role of construction sector in economic growth: Empirical evidence from Pakistan economy. Proceedings: First International Conference on Construction in Developing Countries (ICCIDC-I): Advancing and Integrating Construction Education, Research and Practice. Karachi, Pakistan, 4-5 August.

Kolawole, A. R., Abiodun, A. C., \& Olamide A. R. (2020). A study of the effect of personality characteristics on the effectiveness of construction project managers performance. Covenant Journal of Research in the built environment. Vol. 8(1), 10-21.

Latif, K. F., Nazeer, A., Shahzad, F., Ullah, M., Imranullah, M., \& Sahibzada, U. F. (2020). Impact of entrepreneurial leadership on project success: mediating role of knowledge management processes. Leadership \& Organization Development Journal, 41(2), 237-256. https://doi.org/10.1108/lodj-072019-0323

Low, B. K. L., Man, S. S., Chan, A. H. S., \& Alabdulkarim, S. (2019). Construction Worker Risk-Taking Behavior Model with Individual and Organizational Factors. International Journal of Environmental Research and Public Health, 16(8), 1335-1347. https://doi.org/10.3390/ijerph16081335

Lutas, M., Nistor, R., Radu, M., \& Beleiu, I. (2020). Perceptions Regarding the Profile of an Ideal Project Manager. Www.Amfiteatrueconomic.Ro, 22(54), 608. https://doi.org/10.24818/ea/2020/54/608

Mac Donald, K., Rezania, D., \& Baker, R. (2020). A grounded theory examination of project managers' accountability. International Journal of Project Management, 38(1), 27-35. https://doi.org/10.1016/j.ijproman.2019.09.008

MacLean, L. C., \& Ziemba, W. T. (2013). Handbook of the Fundamentals of Financial Decision Making: Part 2, World Scientific, 99-127. DOI: 10.1142/9789814417358_0016

Macovei, V. \& Hagen, B. (2020, Febrarury 27). Causation, effectuation and bricolage in entry mode decisions. Strategic decision-making in International Context. Proceedings of the $1^{\text {st }}$ Interdisciplinary Workshop, Urbino, Italy: Urbino University Press. 85-113. 
Mahmoudi, A., Abbasi, M., Deng, X., Ikram, M., \& Yeganeh, S. (2020). A novel model for risk management of outsourced construction projects using decision-making methods: a case study. Grey Systems: Theory and Application, 10(2), 97-123. https://doi.org/10.1108/gs-09-2019-0038

Marnewick, A. L., \& Marnewick, C. (2020). The Ability of Project Managers to Implement Industry 4.0Related Projects. IEEE Access, 8, 314-324. https://doi.org/10.1109/access.2019.2961678

Mbogoh, E. W., Mukulu, E., \& Waiganjo. E. (2019). Project implementation in grass-root support nongovernmental organizations in Kenya: is project leadership a determinant. International Journal of Progressive Sciences and Technologies (IJPSAT), Vol. 14(2), 286-289.

McCartney, M. (2020). The China-Pakistan Economic Corridor (CPEC): Infrastructure, Social Savings, Spillovers, and Economic Growth in Pakistan. Eurasian Geography Economics, 1-32.

Musawir, A., Serra, C. E. M., Zwikael, O., \& Ali, I. (2017). Project governance, benefit management, and project success: Towards a framework for supporting organizational strategy implementation. International Journal of Project Management, $35(8), \quad 1658-1672$. https://doi.org/10.1016/j.ijproman.2017.07.007

Naeem, S., Khanzada, B., Mubashir, T., \& Sohail, H. (2018). Impact of Project Planning on Project Success with Mediating Role of Risk Management and Moderating Role of Organizational Culture. International Journal of Business and Social Science 9(1), 88-98.

Nguyen, N. M., Killen, C. P., Kock, A., \& Gemünden, H. G. (2018). The use of effectuation in projects: The influence of business case control, portfolio monitoring intensity and project innovativeness. International Journal of Project Management, 36(8), 1054-1067. https://doi.org/10.1016/j.ijproman.2018.08.005

Pacho, F. T., \& Mushi, H. (2020). The effect of effectuation set of means on new venture performance: Flexibility principle as a mediating factor. Journal of Entrepreneurship in Emerging Economies, Ahead-of-print(Ahead-of-print). doi:10.1108/jeee-02-2020-0023

Perry, J. T., Chandler, G. N., \& Markova, G. (2011). Entrepreneurial Effectuation: A Review and Suggestions for Future Research. Entrepreneurship Theory and Practice, 36(4), 837-861. https://doi.org/10.1111/j.1540-6520.2010.00435.x

Pham, H., Kim, S.-Y., \& Luu, T.-V. (2019). Managerial perceptions on barriers to sustainable construction in developing countries: Vietnam case. Environment, Development and Sustainability, 22(4), 29793003. https://doi.org/10.1007/s10668-019-00331-6

Rehman, S. U. (2020). Impact of Inclusive Leadership on Project Success. Journal of Engineering, Project, and Production Management, 10(2), 87-93. https://doi.org/10.2478/jeppm-2020-0011

Sarasvathy, S. D. (2001). Causation and Effectuation: Toward a Theoretical Shift from Economic Inevitability to Entrepreneurial Contingency. Academy of Management Review, 26(2), 243-263. https://doi.org/10.5465/amr.2001.4378020

Sekaran, U. (2003). Research Methods for Business: A Skill-Building Approach. 4th Edition, John Wiley \& Sons, New York.

Tayeh, B. A., Salem, T. J., Abu Aisheh, Y. I., \& Alaloul, W. S. (2020). Risk Factors Affecting the Performance of Construction Projects in Gaza Strip. The Open Civil Engineering Journal, 14(1), 94104. https://doi.org/10.2174/1874149502014010094

Thoha, N. \& Avandana, I. M. N. W. (2020), Project Managers' Leadership Styles and Their Effects on Project Management Performance, Pertanika Journal of Social Sciences \& Humanities Vol. 28(2), 803-816.

Unterhitzenberger, C., Wilson, H., James Bryde, D., Rost, M., \& Joby, R. (2020). The stakeholder challenge: dealing with challenging situations involving stakeholders. Production Planning \& Control, 1-16. https://doi.org/10.1080/09537287.2020.1776907

Venkatraman, V. \& Wittenbraker, J. (2020). Disrupting Dual Systems: A Dynamic Decision-Making Framework for Human Behavior. SSRN Electronic Journal. https://doi.org/10.2139/ssrn.3607481.

Vroom, V. H., \& Yetton, P. (1973). Leadership and decision-making. University of Pittsburgh Press.

Wu, P., Song, Y., Zhu, J., \& Chang, R. (2019). Analyzing the influence factors of the carbon emissions from China's building and construction industry from 2000 to 2015. Journal of Cleaner Production, 221, 552-566. https://doi.org/10.1016/j.jclepro.2019.02.200 
Yordanova, D. a.-B. (2011). Gender effects on risk-taking of entrepreneurs: evidence from Bulgaria. International Journal of Entrepreneurial Behaviour \& Research, 17(3), 272-295

\section{Appendix}

\section{Questionnaire}

Given below is the scale (Likert- scale) which was used in this questionnaire.

\begin{tabular}{|c|c|c|c|c|}
\hline Strongly disagree & $\begin{array}{c}\text { Moderately } \\
\text { Disagree }\end{array}$ & Neutral & Moderately Agree & Strongly Agree \\
\hline 1 & 2 & 3 & 4 & 5 \\
\hline
\end{tabular}

\begin{tabular}{|c|c|c|c|c|c|c|}
\hline S.N & Questions & $\begin{array}{c}\text { Strongl } \\
\mathbf{y} \\
\text { disagre } \\
\mathbf{e} \\
(1) \\
\end{array}$ & $\begin{array}{c}\text { Modera } \\
\text { tely } \\
\text { Disagre } \\
\text { e } \\
(2) \\
\end{array}$ & $\begin{array}{l}\text { Neutral } \\
(3)\end{array}$ & $\begin{array}{l}\text { Moderat } \\
\text { ely } \\
\text { Agree } \\
\text { (4) }\end{array}$ & $\begin{array}{l}\text { Strongly } \\
\text { Agree } \\
\text { (5) }\end{array}$ \\
\hline 1 & $\begin{array}{l}\text { Available resources and } \\
\text { capabilities have been the starting } \\
\text { point for the project? }\end{array}$ & 1 & 2 & 3 & 4 & 5 \\
\hline 2 & $\begin{array}{l}\text { The project budget was mainly } \\
\text { approved on the basis of } \\
\text { considerations about acceptable } \\
\text { losses? }\end{array}$ & 1 & 2 & 3 & 4 & 5 \\
\hline 3 & $\begin{array}{l}\text { The project was flexible enough to } \\
\text { be adjusted to new findings? }\end{array}$ & 1 & 2 & 3 & 4 & \\
\hline 4 & $\begin{array}{l}\text { Your project planning was carried } \\
\text { out in small steps during the project } \\
\text { implementation? }\end{array}$ & 1 & 2 & 3 & 4 & 5 \\
\hline 5 & $\begin{array}{l}\text { All projects must have a business } \\
\text { case in order to enter the selection } \\
\text { process? }\end{array}$ & 1 & 2 & 3 & 4 & 5 \\
\hline 6 & $\begin{array}{l}\text { Mandatory projects also have to } \\
\text { prove a business case? }\end{array}$ & 1 & 2 & 3 & 4 & 5 \\
\hline 7 & $\begin{array}{l}\text { Do you intensively examine the } \\
\text { business case within project? }\end{array}$ & 1 & 2 & 3 & 4 & 5 \\
\hline 8 & $\begin{array}{l}\text { Have you ever experienced a } \\
\text { situation that you did something } \\
\text { even though it was dangerous? }\end{array}$ & 1 & 2 & 3 & 4 & 5 \\
\hline 9 & $\begin{array}{l}\text { Was your decision on whether } \\
\text { to take risks affected by any } \\
\text { moods? }\end{array}$ & 1 & 2 & 3 & 4 & 5 \\
\hline 10 & $\begin{array}{l}\text { Do you think accidents are } \\
\text { unavoidable even if you are well } \\
\text { prepared or equipped? }\end{array}$ & 1 & 2 & 3 & 4 & 5 \\
\hline 11 & $\begin{array}{l}\text { Do you treat risk taking as a part } \\
\text { of your work? }\end{array}$ & 1 & 2 & 3 & 4 & 5 \\
\hline 12 & $\begin{array}{l}\text { Do you think that having more } \\
\text { work experience will affect your } \\
\text { decision on whether to take or } \\
\text { not take risks? }\end{array}$ & 1 & 2 & 3 & 4 & 5 \\
\hline
\end{tabular}




\begin{tabular}{|c|c|c|c|c|c|c|}
\hline 13 & $\begin{array}{l}\text { Besides the time factors, do you } \\
\text { think that other stresses at work } \\
\text { affect your decision to take risks? }\end{array}$ & 1 & 2 & 3 & 4 & 5 \\
\hline 14 & $\begin{array}{l}\text { Do you think that Safety training } \\
\text { and safety orientation training } \\
\text { encourage you not to take risks? }\end{array}$ & 1 & 2 & 3 & 4 & 5 \\
\hline 15 & $\begin{array}{l}\text { Have you thought about your } \\
\text { family members when you take } \\
\text { risks? }\end{array}$ & 1 & 2 & 3 & 4 & 5 \\
\hline 16 & $\begin{array}{l}\text { If something happens to cause } \\
\text { injury or death to others or } \\
\text { yourself, then your intention and } \\
\text { attitudes toward risk taking will } \\
\text { be similar? }\end{array}$ & 1 & 2 & 3 & 4 & 5 \\
\hline 17 & $\begin{array}{l}\text { Do you think that leaders are able } \\
\text { to affect career planning and } \\
\text { counseling? }\end{array}$ & 1 & 2 & 3 & 4 & 5 \\
\hline 18 & $\begin{array}{l}\text { Do you think that leadership skills } \\
\text { help to maintain an appropriate } \\
\text { knowledge base? }\end{array}$ & 1 & 2 & 3 & 4 & 5 \\
\hline 19 & $\begin{array}{l}\text { Do you think leadership skills } \\
\text { make you understand the need to } \\
\text { work as a group? }\end{array}$ & 1 & 2 & 3 & 4 & 5 \\
\hline 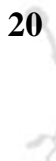 & $\begin{array}{l}\text { Leadership skills demonstrate } \\
\text { patience when the group cannot } \\
\text { reach mutually acceptable } \\
\text { decisions? }\end{array}$ & 1 & 2 & 3 & 4 & 5 \\
\hline 21 & $\begin{array}{l}\text { Leaders with leadership skills show } \\
\text { tolerance for diverse opinion while } \\
\text { decision making? }\end{array}$ & 1 & 2 & 3 & 4 & 5 \\
\hline 22 & $\begin{array}{l}\text { Leaders communicate with the } \\
\text { group and individuals appropriately } \\
\text { in decision making? }\end{array}$ & 1 & 2 & 3 & 4 & 5 \\
\hline 23 & $\begin{array}{l}\text { Do you think that leader } \\
\text { demonstrate an understanding of } \\
\text { what is important and what is not } \\
\text { while decision making? }\end{array}$ & 1 & 2 & 3 & 4 & 5 \\
\hline 24 & $\begin{array}{l}\text { Do you think your leader } \\
\text { introduces new ideas and } \\
\text { approaches to problems at time of } \\
\text { decision making? }\end{array}$ & 1 & 2 & 3 & 4 & 5 \\
\hline 25 & $\begin{array}{l}\text { Do you think your leader can keep } \\
\text { people interested in finishing their } \\
\text { assigned tasks? }\end{array}$ & 1 & 2 & 3 & 4 & 5 \\
\hline 26 & $\begin{array}{l}\text { Your Leader present new and } \\
\text { unique ways of solving problems? }\end{array}$ & 1 & 2 & 3 & 4 & 5 \\
\hline
\end{tabular}

Thank you for your valuable time. 